\title{
Effect of Pretreatments and Drying on the Quality of Oyster Mushrooms
}

\author{
Sharma Anshu* and Bhat Anju \\ Division of Food Science and Technology, Sher-e-Kashmir University of Agricultural \\ Sciences \& Technology of Jammu Main Campus, Chatha - 180 009, Jammu, India \\ *Corresponding author
}

\begin{abstract}
A B S T R A C T

\begin{tabular}{|l|}
\hline K e y w o r d s \\
$\begin{array}{l}\text { Oyster mushrooms, } \\
\text { Pretreatments, Cabinet drying, } \\
\text { Moisture content, Water } \\
\text { activity, Dehydration ratio, } \\
\text { Rehydration ratio, Color, } \\
\text { Browning index, Microbial } \\
\text { count, Sensory evaluation }\end{array}$ \\
\hline Article Info \\
\hline $\begin{array}{l}\text { Accepted: } \\
\text { 04 March } 2018 \\
\text { Available Online: } \\
\text { 10 April 2018 }\end{array}$ \\
\hline
\end{tabular}

\section{Introduction}

Mushrooms assume considerable importance in the human diet as they are rich in nonstarchy carbohydrates, dietary fibre, minerals, vitamin-B and low in fat content. In India, there are mainly three species of mushrooms, namely, white button mushroom (Agaricus bisporus), oyster mushrooms (Pleurotus sajor caju) and paddy straw mushrooms (Volvariella valvacea), that are grown commercially. Among these, oyster mushrooms (Pleurotus sajor caju) possess unique nutritional and medicinal values, characteristic aroma and taste. Oyster mushrooms are suitable for cultivation in plains and even in hilly areas. They contain
\end{abstract}

$89.8 \%$ moisture, $2.9 \%$ protein, $0.36 \%$ fat, $5.3 \%$ carbohydrates, $1 \%$ fiber, $1 \%$ ash and 33.9 Kilocalories of energy. Oyster mushrooms are perishable, because they have a high respiration and transpiration rates leading to rapid post-harvest deterioration. Browning reactions and dehydration affect the shelf-life of fresh oyster mushrooms within a few days, even if refrigerated. Pre-treatment is necessary to check discolouration during mushroom processing (Mudahar and Bains, 1982 and Pruthi et al., 1984). Pre-treatments of mushrooms before drying in one form or other viz., washing in water, potassium metabisulphite (KMS), sugar, salt either alone or in combination help in checking enzymatic browning, stabilizing colour, enhancing 
flavour retention and maintaining textural properties (Singh et al., 2001). Sodium hypochlorite, sodium metabisulphite and glycerol are effective in reducing the browning of dried mushrooms. Addition of glycerol also improves the texture of rehydrated dried mushrooms while $\mathrm{CaCl}_{2}$ produces a firm textured product. Drying is a method of preservation in which the water activity of the food is reduced. Traditionally mushrooms are dried under open sun, which results in unhygienic and poor quality products (Chua et al., 2001). Due to long drying time and overheating of surface during sun drying, the problems of darkening in colour, loss in flavour and decrease in rehydration ability occur. Solar drying can be considered as an elaboration of sun drying and it is an efficient system of utilizing solar energy (Mulhbauer, 1986 and Bala, 1997).

Conventional hot-air drying is one of the most frequently used methods for mushroom dehydration, which involves thermal or chemical pretreatment and drying at temperatures between 50 and $80^{\circ} \mathrm{C}$. In order to avoid darkening of the mushroom surface during hot-air drying, a two phase drying process is employed starting with $30^{\circ} \mathrm{C}$ or $40^{\circ} \mathrm{C}$ followed by a final temperature of $60^{\circ} \mathrm{C}$. Due to low costs of initial investment, operation and ease of controlling the process, convective drying is the most commonly used method in the food industry (Mundada et al., 2010 and Hiranvarachat et al., 2011). The dehydrated product offers, apart from increased shelf life, the advantage of decreased mass and volume which have the potential for savings in the cost of packaging, handling, storage and transport of the product (Amuthan et al., 1999; Karimi, 2010). Therefore, dehydration combined with some pretreatments appear to be a cost effective method of preservation (Rama and Jacob, 2000) for Indian conditions as dehydrated mushrooms are easy to transport as compared to canned, pickled and frozen products (Chandra and Samsher, 2002).

\section{Materials and Methods}

Mushrooms were purchased from M/S Romesh Chander and Sons, Fresh Vegetable and Mushroom Shop, Parade, Jammu. They were washed with tap water and then kept on blotting paper to remove surface moisture. The research was conducted in the department of Food Science and Technology, SKUAST-J. Mushrooms were cut into slices of $1 \mathrm{~cm}$ wide by $1 \mathrm{~cm}$ long for the stipe, while $1.5 \mathrm{~cm}$ by 3 $\mathrm{cm}$ long for the cap and subjected to following pretreatments and then dried in cabinet dryer at temperature $50^{\circ} \mathrm{C}$.

\section{Moisture content}

Ten grams of mushroom were dried in hot air oven at $70^{\circ} \mathrm{C}$ in pre-weighed dishes till constant weight. The dish with dried sample was transferred to desiccators and cooled to room temperature. The dish was then weighed and moisture content in percent was calculated from loss in weight (AOAC, 2002).

$$
\begin{gathered}
\text { Loss in weight }(\mathrm{g}) \\
\text { Percent }(\%) \text { moisture }=\text {--oight of sample }(\mathrm{g})
\end{gathered}
$$

\section{Dehydration ratio}

Dehydration ratio was calculated by taking the weights of sample before drying and the weight of sample after drying.

Weight of sample before drying Dehydration ratio $=$

Weight of sample after drying

\section{Rehydration ratio}

The rehydration ratio of dried mushroom flakes was determined by soaking samples 
with a defined weight (approx. $5 \mathrm{~g}$ ) in boiling distilled water at $95^{\circ} \mathrm{C}$ for 20 minutes. The samples were removed, filtered, dried and weighed. In order to minimize the leaching losses, water bath was used for maintaining the defined temperature (Ranganna, 1986). Rehydration ratio (RR) of the samples was computed as follows:

Rehydration ratio $=\frac{\mathrm{Mr}}{------}$

Where,

$\mathrm{M}_{\mathrm{r}}=$ Mass of rehydrated sample, $\mathrm{g}$;

$M_{d}=$ Mass of dehydrated sample, $g$

\section{Water activity}

Water activity was estimated using Aqualab water activity meter (Model Series: 3TE).

\section{Color}

The color was evaluated by measuring $\mathrm{L}^{*}, \mathrm{a}^{*}$, $b^{*}$ parameters by means of Hunter lab colorimeter.

The instrument was standardized against white tile before the measurements. Color was expressed in CIE-Lab parameters as $\mathrm{L}^{*}$ (whiteness / darkness), a* (redness / greenness), and $b^{*}$ (yellowness / blueness) (Byrnes and O Beirne, 2008).

\section{Browning index}

The degree of non-enzymatic browning of the dried mushrooms was determined following the method of Mudahar and Bains (1982).

The color was extracted from dried mushroom using $60 \%$ ethanol, and the absorbance of the filtrate was measured using a spectrophotometer at $440 \mathrm{~nm}$.

\section{Crude fat}

Five gram of dried sample was extracted with petroleum ether at $120^{\circ} \mathrm{C}$ in Soxhlet extraction apparatus for six hours. Ether extract was filtered in pre-weighed beakers. The petroleum ether was completely evaporated from the beakers and the increase in weight of the beaker represented the fat content (AOAC, 2002) and was calculated as below:

$$
\text { Per cent fat }=\frac{\text { Weight of fat }(\mathrm{g})}{\text { Weight of sample }(\mathrm{g})}
$$

\section{Microbial count}

Spread plate technique described by Palczar and Chan (1997) was used. 1g of each sample was aseptically transferred to $9 \mathrm{ml}$ of sterile water in a separate tube and mixed vigorously. $1 \mathrm{ml}$ of the resulting mixture was transferred to $9 \mathrm{ml}$ of sterile water in a separate tube. The process was continued till 6th dilution $\left(10^{-6}\right)$. Nutrient agar (NA) was inoculated with a 0.1 $\mathrm{ml}$ of appropriately diluted sample $\left(10^{-6}\right)$ by spread plating technique and incubated at $37^{\circ} \mathrm{C}$ for 24 hours. Colonies were counted and multiplied by the dilution factor.

Microbial load $(\mathrm{cfu} / \mathrm{g})=\frac{\mathrm{N} \times 1 \times \mathrm{D}}{\mathrm{V}}$

Where,

$\mathrm{N}=$ Numbers of colonies counted

$\mathrm{V}=$ Volume of inoculums

$\mathrm{D}=$ Dilution factor

\section{Sensory evaluation}

Sensory evaluation depends upon the responses given by different sense organs. The samples were evaluated on the basis of appearance, flavour, texture, taste and overall 
acceptability by semi-trained panel of 9-10 judges by using 9 point hedonic scale assigning scores from 9 (like extremely) to 1 (dislike extremely). A score of 5.5 and above was considered acceptable (Amerine et al., 1965).

\section{Statistical analysis}

The results obtained were statistically analyzed using completely randomized design (CRD) for interpretation of results through analysis of variance.

\section{Results and Discussion}

\section{Moisture content and water activity}

Moisture content of pretreated and dried mushrooms ranged from 8.30 to 8.83 per cent (Table 1). The percent moisture content was highest in $\mathrm{T}_{1}$ (Control) with mean value of 8.83 per cent while mushrooms treated with $1 \%$ glycerol $\left(\mathrm{T}_{7}\right)$ had lowest (8.30 per cent) moisture content. There was significant difference among various treatments. Among various pretreatments, lower moisture content was observed in $1 \%$ glycerol pretreated and cabinet dried mushrooms. These results are in agreement with the findings of Manalo and Benedicto (2014) who reported decrease in moisture content with increase in glycerol concentration in RTE dried tocino. The water activity ranged from 0.44 to 0.59 (Table 1). The highest water activity was recorded in $\mathrm{T}_{1}$ (Control) with mean value of 0.59 followed by $\mathrm{T}_{4}\left(1 \% \mathrm{CaCl}_{2}\right)$ and $\mathrm{T}_{5}\left(2 \% \mathrm{CaCl}_{2}\right)$ with mean values of 0.55 and 0.53 while the lowest water activity was recorded in $\mathrm{T}_{7}(1 \%$ glycerol $)$ and $\mathrm{T}_{6}(0.5 \%$ glycerol $)$ with mean values of 0.44 and 0.46 . Lowest water activity was observed in $1 \%$ glycerol pretreated and cabinet dried mushrooms. Salim et al., (2016) reported lowest water activity in cabinet dried pear at $60^{\circ} \mathrm{C}$ and highest in sun dried pear slices. Samples treated with glycerol reached lower water activity values than those treated with glucose and sucrose. This can be due to glycerol, a polyhydric alcohol which decreased the $a_{w}$ by means of hydrogen binding with it. Panwar et al., (2013) reported the similar results in aonla segments. Manalo and Benedicto (2014) also reported decrease in water activity with increase in glycerol concentration in RTE dried tocino.

\section{Dehydration and rehydration ratio}

The dehydration ratio ranged from 9.38 to 9.84 and there was significant difference among various treatments (Table 1).

The highest dehydration ratio was recorded in mushrooms treated with $1 \%$ glycerol $\left(\mathrm{T}_{7}\right)$ with mean value of 9.84 and lowest (9.38) in $\mathrm{T}_{1}$ (Control) whereas the highest rehydration ratio was recorded in mushrooms treated with $1 \%$ glycerol $\left(\mathrm{T}_{7}\right)$ with mean value of 3.85 and lowest in $\mathrm{T}_{1}$ (Control) with mean value of 2.91. Dehydration and rehydration ratio of pretreated and dried oyster mushrooms were more as compared to untreated mushrooms (control). Similar findings were reported by Doymaz (2014) regarding drying kinetics and rehydration characteristics of convective hotair dried white button mushroom slices.

\section{Color and browning index}

Color is an important quality parameter of mushroom. The $\mathrm{L}^{*}$ value was highest in $\mathrm{T}_{7}$ (1\% glycerol) with mean value of 65.08 while it was lowest in $\mathrm{T}_{1}$ (Control) with mean value of 45.81 (Table 2). The highest $\mathrm{a}^{*}$ (6.42) and $b^{*}$ (26.78) values were recorded in $T_{1}$ (Control) whereas the lowest $\mathrm{a}^{*}$ (3.86) and $\mathrm{b}^{*}$ (19.36) values were recorded in $\mathrm{T}_{7}(1 \%$ glycerol). Oyster mushrooms pretreated with $1 \%$ glycerol showed best color as there was highest $\mathrm{L}^{*}$ value and lowest $\mathrm{a}^{*}$ and $\mathrm{b}^{*}$ values as compared to control. Similar results were observed by (Mohamed and Hoo, 1994). 
Table.1 Effect of pretreatments on moisture content (\%), water activity $\left(\mathrm{a}_{\mathrm{w}}\right)$, dehydration ratio and rehydration ratio of dried oyster mushrooms

\begin{tabular}{|c|c|c|c|c|}
\hline Pre-treatments & $\begin{array}{c}\text { Moisture content } \\
(\%)\end{array}$ & Water activity & $\begin{array}{c}\text { Dehydration } \\
\text { ratio }\end{array}$ & $\begin{array}{l}\text { Rehydration } \\
\text { ratio }\end{array}$ \\
\hline $\mathrm{T}_{1}($ Control $)$ & 8.83 & 0.59 & 9.38 & 2.91 \\
\hline $\mathrm{T}_{2}(0.1 \% \mathrm{KMS})$ & 8.65 & 0.51 & 9.60 & 3.73 \\
\hline $\mathrm{T}_{3}(0.2 \% \mathrm{KMS})$ & 8.50 & 0.48 & 9.62 & 3.79 \\
\hline $\mathrm{T}_{4}\left(1 \% \mathrm{CaCl}_{2}\right)$ & 8.72 & 0.55 & 9.44 & 3.66 \\
\hline $\mathrm{T}_{5}\left(2 \% \mathrm{CaCl}_{2}\right)$ & 8.70 & 0.53 & 9.47 & 3.70 \\
\hline $\mathrm{T}_{6}(0.5 \%$ Glycerol $)$ & 8.40 & 0.46 & 9.81 & 3.78 \\
\hline $\mathrm{T}_{7}(1 \%$ Glycerol $)$ & 8.30 & 0.44 & 9.84 & 3.85 \\
\hline Mean & 8.58 & 0.51 & 9.59 & 3.63 \\
\hline $\mathrm{CD}_{(0.05)}$ & 0.09 & 0.08 & 0.08 & 0.08 \\
\hline \pm S.E. $(\mathrm{m})$ & 0.03 & 0.02 & 0.02 & 0.02 \\
\hline
\end{tabular}

Table.2 Effect of pretreatments on color and browning index of dried oyster mushrooms

\begin{tabular}{|c|c|c|c|c|}
\hline \multirow[t]{2}{*}{ Pre-treatments } & \multicolumn{3}{|c|}{ Color } & \multirow[t]{2}{*}{ Browning index } \\
\hline & $\mathbf{L}^{*}$ & $\mathbf{a}^{*}$ & $\mathbf{b}^{*}$ & \\
\hline $\mathrm{T}_{1}$ (Control) & 45.81 & 6.42 & 26.78 & 0.98 \\
\hline $\mathrm{T}_{2}(0.1 \% \mathrm{KMS})$ & 58.20 & 5.24 & 24.39 & 0.14 \\
\hline $\mathrm{T}_{3}(0.2 \% \mathrm{KMS})$ & 58.36 & 5.18 & 24.18 & 0.13 \\
\hline $\mathrm{T}_{4}\left(1 \% \mathrm{CaCl}_{2}\right)$ & 62.29 & 4.28 & 20.42 & 0.05 \\
\hline $\mathrm{T}_{5}\left(2 \% \mathrm{CaCl}_{2}\right)$ & 63.11 & 4.15 & 20.19 & 0.04 \\
\hline $\mathrm{T}_{6}(0.5 \%$ Glycerol $)$ & 64.24 & 3.98 & 19.62 & 0.06 \\
\hline $\mathrm{T}_{7}(1 \%$ Glycerol $)$ & 65.08 & 3.86 & 19.36 & 0.04 \\
\hline Mean & 59.58 & 4.73 & 22.13 & 0.20 \\
\hline $\mathrm{CD}_{(0.05)}$ & 0.12 & 0.11 & 0.12 & 0.08 \\
\hline \pm S.E.(m) & 0.04 & 0.04 & 0.04 & 0.03 \\
\hline
\end{tabular}

$\mathrm{L}^{*}$ (Whiteness/darkness)

$\mathrm{a}^{*}$ (redness/greenness)

b* (yellowness/blueness)

Table.3 Effect of pretreatments on crude fat (\%) and microbial count (cfu/g) of dried oyster mushrooms

\begin{tabular}{|c|c|c|}
\hline Pre-treatments & Crude fat (\%) & Microbial count $\left(\times 10^{2} \mathrm{cfu} / \mathrm{g}\right)$ \\
\hline $\mathrm{T}_{1}($ Control $)$ & 1.31 & 1.93 \\
\hline $\mathrm{T}_{2}(0.1 \% \mathrm{KMS})$ & 1.77 & 1.47 \\
\hline $\mathrm{T}_{3}(0.2 \% \mathrm{KMS})$ & 1.79 & 1.42 \\
\hline $\mathrm{T}_{4}\left(1 \% \mathrm{CaCl}_{2}\right)$ & 1.73 & 1.54 \\
\hline $\mathrm{T}_{5}\left(2 \% \mathrm{CaCl}_{2}\right)$ & 1.76 & 1.51 \\
\hline $\mathrm{T}_{6}(0.5 \%$ Glycerol $)$ & 1.82 & 1.36 \\
\hline $\mathrm{T}_{7}(1 \%$ Glycerol $)$ & 1.88 & 1.32 \\
\hline Mean & 1.72 & 1.51 \\
\hline $\mathbf{C D}_{(0.05)}$ & 0.08 & 0.09 \\
\hline \pm S.E.(m) & 0.03 & 0.03 \\
\hline
\end{tabular}


Table.4 Effect of pretreatments on appearance, flavour, texture, taste and overall acceptability of dried oyster mushrooms

\begin{tabular}{|c|c|c|c|c|c|}
\hline Pre-treatments & Appearance & Flavour & Texture & Taste & $\begin{array}{c}\text { Overall } \\
\text { acceptability }\end{array}$ \\
\hline $\mathrm{T}_{1}$ (Control) & 7.08 & 6.84 & 6.96 & 6.81 & 6.94 \\
\hline $\mathrm{T}_{2}(0.1 \% \mathrm{KMS})$ & 8.43 & 8.05 & 8.15 & 8.03 & 8.15 \\
\hline $\mathrm{T}_{3}(0.2 \% \mathrm{KMS})$ & 8.47 & 8.10 & 8.18 & 8.10 & 8.21 \\
\hline $\mathrm{T}_{4}\left(1 \% \mathrm{CaCl}_{2}\right)$ & 8.40 & 7.90 & 8.22 & 7.91 & 8.07 \\
\hline $\mathrm{T}_{5}\left(2 \% \mathrm{CaCl}_{2}\right)$ & 8.44 & 7.97 & 8.28 & 7.96 & 8.14 \\
\hline $\mathrm{T}_{6}(0.5 \%$ Glycerol $)$ & 8.56 & 8.19 & 8.35 & 8.21 & 8.27 \\
\hline $\mathrm{T}_{7}(1 \%$ Glycerol $)$ & 8.62 & 8.25 & 8.44 & 8.27 & 8.33 \\
\hline Mean & 8.28 & 7.90 & 8.08 & 7.89 & 8.01 \\
\hline $\mathrm{CD}_{(0.05)}$ & 0.07 & 0.07 & 0.08 & 0.07 & 0.07 \\
\hline \pm S.E.(m) & 0.02 & 0.02 & 0.03 & 0.02 & 0.02 \\
\hline
\end{tabular}

Treatment details

\begin{tabular}{|c|}
\hline Pre-treatments \\
\hline $\mathrm{T}_{1}$ \\
\hline $\mathrm{T}_{2}$ \\
\hline $\mathrm{T}_{3}$ \\
\hline $\mathrm{T}_{4}$ \\
\hline $\mathrm{T}_{5}$ \\
\hline $\mathrm{T}_{6}$ \\
\hline $\mathrm{T}_{7}$ \\
\hline
\end{tabular}

\begin{tabular}{|c|}
\hline Detail \\
\hline Control \\
\hline $0.1 \% \mathrm{KMS}$ \\
\hline $0.2 \% \mathrm{KMS}$ \\
\hline $1 \% \mathrm{CaCl}_{2}$ \\
\hline $2 \% \mathrm{CaCl}_{2}$ \\
\hline $0.5 \%$ Glycerol \\
\hline $1.0 \%$ Glycerol \\
\hline
\end{tabular}

Fig.1 Effect of pretreatments on overall acceptability of dried oyster mushrooms

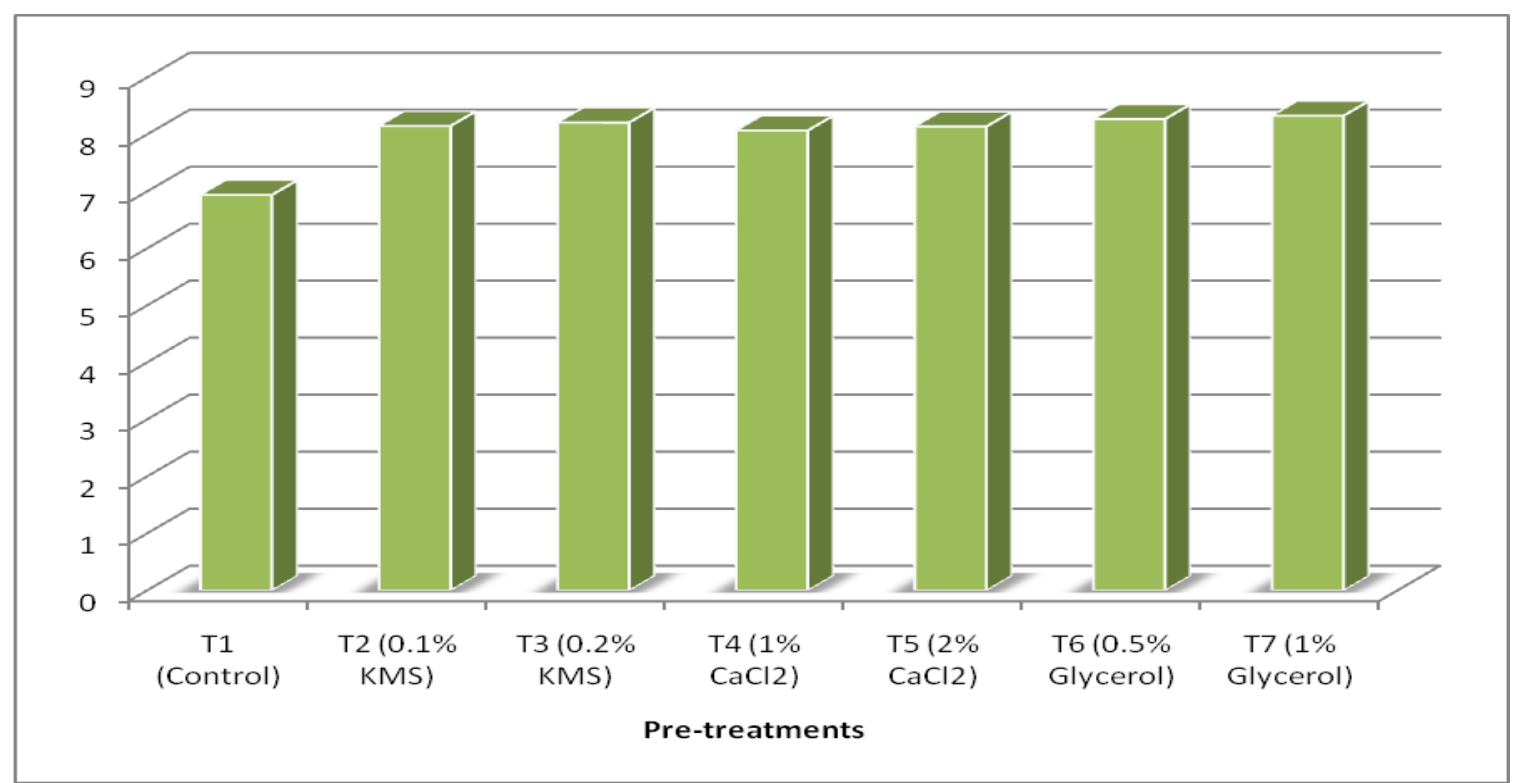


Farahnaky et al., (2013) reported that L value increased, $a$ and $b$ values decreased with increase in glycerol concentration as compared to control in wheat starch edible films. The browning index of mushrooms is related to change in color of mushrooms. As the $\mathrm{L}^{*}$ value decreased and $\mathrm{a}^{*}$ and $\mathrm{b}^{*}$ value increased, the browning index increased (Table 2). The highest browning index was observed in $\mathrm{T}_{1}$ (Control) with mean value of 0.98 . The browning index was recorded to be lowest $(0.04)$ in $\mathrm{T}_{5}\left(2 \% \mathrm{CaCl}_{2}\right)$ and it was at par with $\mathrm{T}_{7}(1 \%$ glycerol) with mean value of 0.04. Chakraborty et al., (2014) also observed lower browning index in glycerol monostearate treated samples as compared to samples not containing glycerol monostearate regarding the study of functional properties based statistical optimization of foam mat drying parameters for potato (Kufri Chandramukhi).

\section{Crude fat and microbial count}

The crude fat of various pretreatments ranged from 1.31 to 1.88 per cent (Table 3 ). The crude fat was highest (1.88 per cent) in mushrooms treated with $1 \%$ glycerol $\left(\mathrm{T}_{7}\right)$ and it was at par with $\mathrm{T}_{6}(0.5 \%$ glycerol $)$ with mean value of 1.82 per cent while it was lowest (1.31 per cent) in $\mathrm{T}_{1}$ (Control). Crude fat contents were more in pretreated oyster mushrooms as compared to untreated mushrooms. Similar findings were reported by Dunkwal et al., (2007) regarding physicochemical properties and sensory evaluation of Pleurotus sajor caju powder as influenced by pre-treatments and drying methods and also Ibrahim et al., (2017) in oyster mushrooms. The highest $\left(1.93 \times 10^{2} \mathrm{cfu} / \mathrm{g}\right)$ microbial count (Table 3) was recorded in $\mathrm{T}_{1}$ (Control) while it was lowest $\left(1.32 \times 10^{2} \mathrm{cfu} / \mathrm{g}\right)$ in $\mathrm{T}_{7}(1 \%$ glycerol) and it was at par with $\mathrm{T}_{6}(0.5 \%$ glycerol) with mean value of $\left(1.36 \times 10^{2} \mathrm{cfu} / \mathrm{g}\right)$. Microbial count in pretreated and dried oyster mushrooms was low as compared to untreated mushrooms (control). Similar results were observed by Ibrahim et al., (2017) regarding effect of pre-treatments and drying methods on the chemical quality and microbial density of wild edible oyster mushroom.

\section{Sensory evaluation}

Sensory evaluation of pretreated and dried mushrooms was done using 9-point hedonic rating scale. Mushrooms treated with various chemicals attained more score for overall acceptability as compared to control (Table 4). The highest overall acceptability rating was recorded in $\mathrm{T}_{7}(1 \%$ glycerol) with mean value of 8.33 while it was lowest in $T_{1}$ (Control) with mean value of 6.94. Pretreated dried oyster mushrooms scored higher sensory scores than untreated mushrooms in terms of color, flavour, texture, taste and overall acceptability (Fig. 1).

Among various pretreatments, mushroom samples pretreated with $1 \%$ glycerol and cabinet dried were adjudged best based on overall sensory score. Glycerol treated samples had a better color as they showed higher $\mathrm{L}^{*}$ value but relatively lower $\mathrm{a}^{*}$ and $\mathrm{b}^{*}$ values. Glycerol pretreatment improved the texture score of dried mushrooms. Glycerol treated mushroom samples showed a softer texture than $\mathrm{CaCl}_{2}$ and $\mathrm{KMS}$ pretreated mushrooms because it function as a solvent which replaces water in dried product. Glycerol has also been reported to reduce shrinkage during drying, maintain texture and improve the ability to rehydrate to a level of fresh mushrooms. Similar findings were observed by (Mohamed and Hoo, 1994). These results are in agreement with the findings of Srivastava and Bala (2016) also reported that $1 \%$ gum-arabic associated with $1 \%$ carboxymethyl cellulose and $1 \%$ glycerol coating was effective in increasing the shelf life of button mushrooms. Kim et al., (2013) also reported that organoleptic scores were 
higher in glycerol pretreated and hot air dried jujube fruits regarding effect of pretreatment and drying methods on quality and antioxidant activities of dried jujube fruits (Zizyphus jujuba).

\section{Acknowledgement}

This study was funded by Sher-e-Kashmir University of Agricultural Sciences \& Technology of Jammu, Chatha, Jammu.

\section{References}

Amerine, M. A., Pangborn, R. H. and Rossler, E. B. 1965. Principles of Sensory Evaluation of Food. Academic press, New York.

Amuthan, G., Visvanathan, R., Kailappan, R. and Sreenarayanan, V. V. 1999. Studying of osmo-air drying of milky mushroom Calocybe indica. Mushroom Research, 8: 49-52.

AOAC, 2002. Official methods of analysis. Association of Analytical Chemists, Washington, DC.

Bala, B. K. 1997. Drying and Storage of Cereal Grains. Oxford \& IBH Publishing Co. Private Ltd., India.

Byrnes, C. V. and O Beirne, D. 2008. Effects of washing treatment on microbial and sensory quality of modified atmosphere (MA) packaged fresh sliced mushroom (Agaricus bisporus). Postharvest Biology and Technology, 72: 197-204.

Chakraborty, S., Banerjee, S. and Majumder, S. 2014. Functional properties based statistical optimization of foam mat drying parameters for potato (Kufri Chandramukhi). Global Journal of Science Frontier Research, 14 (2): 1-10.

Chandra, S. and Samsher, S. 2002. Studies on quality of dehydrated oyster mushroom as influenced by various pre-treatments and drying method. Mushroom Research, 11: 107-112.
Chua, K. J., Mujumdar, A. S., Hawlader, M. N. A., Chou, S. K. and Ho, J. C. 2001. Batch drying of banana pieces-effect of stepwise change in drying air temperature on drying kinetics and product colour. Food Research International, 34: 721-731.

Doymaz, I. 2014. Drying kinetics and rehydration characteristics of convective hot-air dried white button mushroom slices. Journal of Chemistry, pp. 1-8.

Dunkwal, V., Jood, S. and Singh, S. 2007. Physico-chemical properties and sensory evaluation of Pleurotus sajor caju powder as influenced by pretreatments and drying methods. British Food Journal, 109 (9): 749-759.

Farahnaky, A., Saberi, B. and Majzoobi, M. 2013. Effect of glycerol on physical and Mechanical properties of wheat starch edible films. Journal of Texture Studies, 44 (3): 176-186.

Hiranvarachat, B., Devahastin, S. and Chiewchan, N. 2011. Effects of acid pretreatments on some physicochemical properties of carrot undergoing hot-air drying. Food and Bioproducts Processing, 89: 116-127.

Ibrahim, T. A., Adaramola-Ajibola, K. M., Adesuyi, A. T., Olenrewaju, S. O. and Akinro, E. B. 2017. Effect of pretreatments and drying methods on the chemical quality and microbial density of wild edible oyster mushroom. Archive of Food and Nutritional Science, 1: 39-44.

Karimi, F. 2010. Applications of superheated steam for the drying of food products. International Agrophysics, 24: 195-204.

Kim, J. W., Lee, S. H., No, H. K., Hong, J. H., Park, C. S. and Youn, K. S. 2013. Effect of pretreatment and drying methods on quality and antioxidant activities of dried jujube (Zizyphus jujuba) fruit. Journal of the Korean 
Society of Food Science and Nutrition, 42(8): 1242-1248.

Manalo, M. and Benedicto, A. 2014. Effect of different humectants in the physicochemical properties of ready-to-eat (RTE) tocino. De La Salle University Research Congress, Manila, Philippines.

Mohamed, S. and Hoo, T. S. 1994. Effect of pretreatments on the characteristics of dried grey oyster mushroom. Pertanika Journal of Tropical Agricultural Science, 17(2): 111-115.

Mudahar, G. S. and Bains. S. 1982. Pretreatment effect on quality of dehydrated Agaricus Bisporus mushroom. Indian Food Packer, 36 (3): 19-27.

Muhlbauer, W. 1986. Present status of solar crop drying. Energy in Agriculture, 5: 121-37.

Mundada, M., Hathan, B. S. and Maske, S. 2010. Convective dehydration kinetics of osmotically pretreated pomegranate arils. Biosystems Engineering, 107: 307-316.

Palczar, M. J. and Chan, E. C. S. 1997. Laboratory Exercise in Microbiology. Black Dot Inc., New York.

Panwar, S., Gehlot, R. and Siddiqui, S. 2013. Effect of osmotic agents on intermediate moisture aonla segments during storage. International Journal of Agricultural Food Science and Technology, 4: 537-542.
Pruthi, J. S., Manan, J. K., Raina, B. L. and Teotia, M. S. 1984. Improvement in whiteness and extension of shelf life of fresh and processed mushrooms, Agaricus bisporus and Volvariella volvacea. Indian Food Packer, 38 (2): 55-63.

Rama, V. and John, P. J. 2000. Effects of methods of drying and pretreatments on quality of dehydrated mushroom. Indian Food Packer, 54 (5): 59-64.

Ranganna, S. 1986. Manual of Analysis of Fruits and Vegetable Products. Tata McGraw Hill Publishing Company Ltd. New Delhi.

Salim, R., Rather, A. H. and Naik, H. R. 2016. Influence of osmotic pretreatments and drying methods on water activity of dried pear. Biosciences Biotechnology Research Asia, 13 (3): 1607-1610.

Singh, S. K., Narain, M., Kumbhar, B. K. 2001. Effect of drying air temperatures and standard pretreatments on the quality of fluidized bed dried button mushroom (Agaricus bisporus). Indian Food Packer, 55 (5): 82-86.

Srivastava, S. and Bala, L. K. 2016. Effect of arabic-gum carboxymethyl cellulose edible coatings on shelf life of button mushroom (Agaricus bisporus). International Journal of Research in Engineering and Technology, 5 (6): 484-494.

\section{How to cite this article:}

Sharma Anshu and Bhat Anju. 2018. Effect of Pretreatments and Drying on the Quality of Oyster Mushrooms. Int.J.Curr.Microbiol.App.Sci. 7(04): 93-101. doi: https://doi.org/10.20546/ijcmas.2018.704.011 